\title{
Studies of Arteriosclerosis in Japanese and American Men
}

\author{
I. COMPARISON OF FATTY ACID \\ COMPOSITION OF ADIPOSE TISSUE
}

\author{
Wiflitam Insull, Jr., P. Dieter Lang, \\ Bartholomew P. Hsi, and Saburo Yoshmmura \\ From School of Medicine, Keio University, Tokyo, Japan; Departments of \\ Medicine and Biometry, Case Western Reserve University, Cleveland, \\ Ohio 44106; and Office of Medical Examiner of Metropolitan Tokyo, \\ Tokyo, Japan
}

A B S T R A C T The proportions of fatty acids in lipids of subcutaneous adipose tissue was compared in closely age-matched, urban men from two populations with a great difference in mortality from arteriosclerosis, namely in 50 Americans and 56 Japanese aged 15-65 yr who had died suddenly and unexpectedly. Specimens from both groups were analyzed side by side for fatty acids by gas-liquid chromatography. Compared with Japanese, Americans had significantly $(P<0.01)$ higher proportions of lauric $(+0.2 \%)$, myristic $(+0.4 \%)$, palmitic $(+1.4 \%)$, stearic $(+2.2 \%)$, and oleic $(+5.3 \%)$ and lesser of palmitoleic $(-1.8 \%)$, linoleic $(-6.3 \%)$, and linolenic $(-0.4 \%)$ acids. Japanese had higher proportions of longer chain polyunsaturated fatty acids. The distributions of fatty acids for the groups at ages 35-44 yr had significant differences. With age, Americans showed significant increases of palmitic and oleic acids and decreases of lauric, myristic, stearic, and linoleic acids; Japanese showed no correlations of proportions of fatty acids with age. The significant correlations between per cent standard body weight and fatty acids in Americans were positive for palmitic and negative for lauric and stearic

This work was published in part in abstract form (1).

Dr. Insull was a Visiting Lecturer, School of Medicine, Keio University, Tokyo, in 1966-1967. and performed this study during tenure of an Established Investigatorship of the American Heart Association. Dr. Lang, an Awardee of the Deutsche Forschungsgemeinschaft, was a Research Fellow, School of Medicine, Keio University, Tokyo, and a Research Associate, Case Western Reserve University. His present address is Medizinische Universitaetsklinik, Heidelberg, West Germany.

Received for publication 14 November 1968 and in revised form 5 February 1969. acids, and in Japanese, negative for myristic acid. The patterns of interacid correlations were dissimilar for the groups. These patterns may be stable characteristics of these groups providing further insight into their fatty acid metabolism. The relationships with the fatty acid compositions of the American and Japanese diets are discussed.

\section{INTRODUCTION}

Arteriosclerotic heart disease occurs in Japanese with rates of incidence and mortality one quarter or less of the rates of Americans $(2,3)$. The factors responsible for this difference are poorly understood although knowledge about them might aid in treating this disease and controlling its development in the United States. The Japanese appear to be susceptible to the development of advanced stages of arteriosclerosis since Japanese living in Hawaii and the continental United States experience mortality rates from arteriosclerosis greater than those of Japanese in Japan (4). This indicates that the development of this disease may be controlled in part by factors in the environment.

Salient differences between the Japanese and Americans as regards arteriosclerosis are that the former have less extensive and less advanced development of lesions of arteriosclerosis $(5,6)$ and their concentrations of cholesterol in plasma are among the lowest observed in technicologically advanced countries $(7,8)$. Since arterial lesions of arteriosclerosis show prominent accumulations of lipids, altered lipid metabolism appears as a hallmark of the disease and provides an obvious avenue for investigation of its pathogenesis.

To describe and characterize further the differences 
between these groups that may account for the differences in morbidity and mortality from arteriosclerosis, we have compared the characteristics of arteriosclerosis of the thoracic aorta and the concentration and composition of lipids in various tissues in Japanese and American men during the development of arteriosclerosis. Our results will appear in a series of reports, of which this, the first, is concerned with a comparison between the fatty acid composition of adipose tissue of Japanese and American men. Fatty acids in the diet, and possibly in adipose tissue, may directly control the development of arteriosclerosis by influencing the concentration of plasma cholesterol (9-11). Adipose tissue fatty acids may directly influence the development of arteriosclerosis by being the major source of fatty acids in the internal environment through their mobilization and rapid flux as free fatty acids of plasma. The proportionate distribution of certain fatty acids of adipose tissue appears to correlate with the severity of coronary arteriosclerosis in Americans (12). The characteristics of the national diet of the Japanese, potentially the major factor of the environment influencing arteriosclerosis and the fatty acid composition of adipose tissue, have been described in detail (13). Relative to the diet of Americans, the diet of Japanese is lower in the proportion of total calories derived from fat, and the fat is largely provided as vegetable foods. The Japanese diet has a higher proportion of carbohydrate with most of it in the form of complex polysaccharides; the protein content is similar to that of the American diet but is provided largely in vegetable foods.

General design of study. The study was designed to obtain a comparison between the extent and lipid content of arteriosclerosis of the aorta and the lipid content of various tissues of contemporary Japanese and American men at autopsy. All subjects had died suddenly and unexpectedly, and were ostensibly healthy before death. The subjects of each group were evenly distributed by age over the years encompassing the development of arteriosclerosis; this made possible the measurement of associations of various chemical changes with age and with the disease. The goal was to obtain 10 subjects of each race group in each decade (a groupdecade cell) for five decades, a total of 50 subjects in each of the two groups. With the expectation that Americans had an earlier and more rapid development of arteriosclerosis than the Japanese, the youngest decade for Americans was the second, and for the Japanese the third, whereas the oldest decade for Americans was the sixth, and for the Japanese the seventh. For some studies extra subjects were added to this core collection. To be able to test for associations among the concentrations and compositions of lipids in various tissues, we sampled aorta, serum, liver, muscle, skin, and adipose tissue from each subject at necropsy. Due to the vagaries of availability of subjects and tissues some group-decade cells were not completed and not all tissues were obtained on each subject. When collection of specimens was concluded, analyses were begun. All analytical procedures were standardized to minimize laboratory error. Random numbers were used to determine the order of selection of samples and a master schedule for the sequence of all analyses. Japanese and American specimens were paired for analyses side by side. For each decade of age of each race group all available samples were arranged in order of date of collection and 10 samples were selected for analysis. The 10 specimens selected from the Japanese were paired with specimens from the Americans of the same decade of age to obtain matching within the decade of age. Specimens from the teen-aged Americans were paired with those from Japanese sextagenarians when there were insufficient specimens for matching within the same decades of age. The order of laboratory analysis of these JapaneseAmerican pairs was scheduled by identifying the decades in random order and selecting from each a Japanese-American pair of subjects. When all the decades had been sampled once, a cycle was completed, and the procedure was repeated until, with a total of $10 \mathrm{cy}-$ cles, all pairs of subjects had been selected. The sequence of these 50 selections was the master schedule for all analyses in so far as possible. Incomplete pairs were analyzed in the proper sequence. Deviations from this scheme, as in studies with extra subjects, have been noted.

\section{METHODS}

Tissue specimens. Tissues were obtained from men dying suddenly and unexpectedly, 50 Caucasian and Negro American men dying in Cleveland July 2 to August 19, 1966, and 56 Japanese men in Tokyo September 15 to December 18, 1966. These included 11 Americans and 7 Japanese added to the 4th and 5th decades of the core collection for the study of fatty acid distribution. The distribution of cases by decade of age and race is summarized in Table I. The causes of death are summarized in Table II. No subject showed evidence of cachexia or debilitating disease. The autopsy diagnoses of cause of death in the two groups cannot be strictly compared, particularly for heart disease, because of differences in diagnostic criteria and pathological practices. For example, pokkuri, the Japanese term for sudden death without obvious pathological changes and felt to be owing to acute circulatory failure, was diagnosed in five Japanese subjects. Nonetheless, in our groups Americans clearly had a much higher incidence of arteriosclerotic heart disease than did Japanese. In Americans, recent or remote myocardial infarction or coronary artery occlusion was the cause of death or an incidental observation in 12 cases. In the Japanese only one, a $61 \mathrm{yr}$ old, demonstrated coronary artery thrombosis; no other cases of remote coronary occlusion, recent or remote myocardial infarction, or significant stenosis of the trunk of the coronary arteries were observed. Japanese characteristically had a higher incidence 
TABLE I

Numbers of Cases by Race and Decade of Age

\begin{tabular}{lrrrrrrr}
\hline & \multicolumn{6}{c}{ Decade of age } & \\
\cline { 2 - 6 } \multicolumn{1}{c}{ Group } & 2 & 3 & 4 & 5 & 6 & 7 & Total \\
\hline American & & & & & & & \\
$\quad \begin{array}{l}\text { Caucasian } \\
\text { Negro }\end{array}$ & - & 5 & 3 & 15 & 9 & - & \\
Japanese & 1 & 11 & 15 & 13 & 10 & 6 & 56 \\
\hline
\end{tabular}

of cerebrovascular hemorrhage. Diabetes mellitus was an incidental diagnosis once in each group.

The weight of each individual in the nude was compared to a standard for the same height. The standard for Americans was the average weight recently observed for clothed men at age 25-29 yr corrected for 1 inch shoe heel height and $3 \mathrm{lbs}$ of clothing (14). The standard for Japanese was the 50th percentile weight value for nude men at age 25-29 yr from measurements in Hiroshima and Nagasaki (15). These standards, while not strictly appropriate, are the best available for evaluating the weights of our subjects. Subjects with cachexia may have severe distortion of the composition of their adipose tissue. In preliminary studies 10 Japanese with an average age of $67.8 \mathrm{yr}$ and body weights averaging $75 \%$ of their standard weights, had scanty, intensely yellow adipose tissues usually with a marked reduction in its concentration of triglyceride. The fatty acid composition of these specimens was significantly different from that of the sudden death subjects having a higher proportion of oleic and lower proportion of linoleic acids. The concentration of cholesterol in the serum, liver, and skeletal muscle of these subjects appeared abnormal also. None of the subjects in the present study had these characteristics.

Specimens of subcutaneous adipose tissue were obtained at autopsy from the midline of the anterior abdominal wall. They were received in the form of the full thickness of the abdominal wall from the edge of the autopsy incision including skin, fat, and muscle, $3 \mathrm{~cm}$ wide and $6 \mathrm{~cm}$ long. Tissues were moistened with physiological saline solution, sealed in a vapor-barrier plastic bag, ${ }^{1}$ frozen at $-15^{\circ} \mathrm{C}$, and stored for 6-12 months before analysis. A previous study has shown no effect of storage on fatty acid composition under these conditions (16). The total cholesterol content of these adipose tissues was determined in the random sequence of matched pairs described above. Weighed tissue specimens were minced, extracted with ethanol: ether $(2: 1)$, and their steroids precipitated with digitonin and measured by the Liebermann-Burchard reaction (17). No significant difference between Japanese and Americans in the total cholesterol concentrations was observed, $98.3 \pm 31.4 \mathrm{mg} / 100 \mathrm{~g}$ of tissue for 48 of the Japanese vs. $105 \pm 34 \mathrm{mg} / 100 \mathrm{~g}$ of tissue for 38 of the Ámericans. These values have reasonable agreement with the value of $85.9 \pm 17.2 \mathrm{mg} / 100 \mathrm{~g}$ reported by Vague and Garrigues (18).

Fatty acid analysis. The tissue specimens were thawed, cut, and duplicate $30-\mathrm{mg}$ samples removed from the center of the fresh cut. The tissue sample was minced with scissors, transferred to a bottle with $20 \mathrm{ml}$ of a $1: 1$ mixture of isopropyl alcohol and petroleum ether $\left(\right.$ bp $30-60^{\circ} \mathrm{C}$ ), containing $1 \mu \mathrm{l}$ of $\alpha$-tocopherol and $4 \mathrm{mg}$ of ethylene diaminetetraacetic acid as antioxidants, and extracted for 1 or more $\mathrm{hr}$.

\footnotetext{
${ }^{2}$ Mylar Pouch, J. R. Blaide Co., Cleveland, Ohio.
}

TABLE II

Autopsy Diagnosis of Cause of Death

\begin{tabular}{|c|c|c|}
\hline \multirow[b]{2}{*}{ Diagnosis } & \multicolumn{2}{|c|}{ No. of cases } \\
\hline & American & Japanese \\
\hline Heart disease & 19 & 29 . \\
\hline Cerebrovascular hemorrhage & 3 & 12 \\
\hline Ruptured aortic aneurysm & 1 & \\
\hline Acute trauma & 18 & 4 \\
\hline Primary pneumonia & 3 & 2 \\
\hline Acute poisoning & 3 & 3 \\
\hline Mechanical asphyxia & 2 & 3 \\
\hline $\begin{array}{l}\text { One each of anaphylaxis, } \\
\text { pancreatitis, electrocution, } \\
\text { and kidney tumor }\end{array}$ & 1 & 3 \\
\hline Totals & 50 & 56 \\
\hline
\end{tabular}

The solvent mixture was prepared weekly from redistilled reagent grade solvents. The protein was removed by filtration. The filtrate was washed twice with distilled water. A $1 \mathrm{ml}$ aliquot was evaporated to dryness by a nitrogen stream and after adding five drops of benzene and $1 \mathrm{ml}$ of $5 \% \mathrm{HCl}$ in super-dry methanol, it was heated at $75^{\circ} \mathrm{C}$ overnight in a sealed tube to interesterify the fatty acids. After addition of $1 \mathrm{ml}$ of $\mathrm{H}_{2} \mathrm{O}$ the methyl esters of the fatty acids were recovered by extracting three times with hexane. The hexane solution was neutralized with $\mathrm{NaHCO}_{3}$ and dehydrated with anhydrous $\mathrm{Na}_{2} \mathrm{SO}_{4}$. After evaporation of the extract to dryness by a nitrogen stream the methyl esters were dissolved in $150 \mu \mathrm{l}$ carbon disulfide. A $2 \mu \mathrm{l}$ aliquot, containing about $100 \mu \mathrm{g}$ of methyl esters, was analyzed by gas-liquid chromatography. Preliminary tests by quantitative thin-layer chromatography showed that interesterification was at least $91 \%$ complete. All glassware was cleaned in acid-dichromate solution.

Gas-liquid chromatography was carried out with an

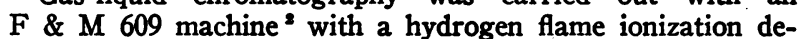
tector run at a constant attenuation of $100 \times 16$. The $10 \mathrm{ft} \times$ $\frac{1}{8}$ inch $\mathrm{OD}$ aluminum tubing columns were packed with $15 \%$ diethylene glycol succinate on 60-80 mesh Chromosorb W. $^{3}$ The carrier gas was helium. The column temperature was $195^{\circ} \mathrm{C}$, the injection port temperature $275^{\circ} \mathrm{C}$, and detector temperature $250^{\circ} \mathrm{C}$. The columns had a minimum column efficiency of 2500 theoretical plates at stearate and a stearateoleate separation factor of 1.14. The area under each peak of the chromatographic records was measured by triangulation (height $\times \frac{1}{2}$ width of base). Peaks for each acid from lauric acid to an unidentified acid with the retention volume of 3.63 , relative to stearate, were measured. The total area under all the peaks was equated to $100 \%$ and the relative percentage of each fatty acid was calculated. The average of the single chromatograms of the duplicate tissue samples was used for further data analysis. The fatty acid methyl esters were identified by comparing the retention volumes with those of pure fatty acid methyl esters $(14: 0,16: 0,18: 0,22: 0)^{6}$ $(20: 4,20: 5,22: 6) .^{8}$ The retention volume of linolenic acid

F. \& M. Scientific Corp., Avondale, Pa.

- Shimadzu Seisakusho Ltd., Koyoto, Japan.

- Applied Science Laboratories Inc., State College, Pa.

${ }^{5}$ Hormel Institute, Austin, Minn. 
TABLE III

Proportions of Fatty Acids in Adipose Tissue of American and Japanese Men

\begin{tabular}{|c|c|c|c|c|c|c|c|}
\hline \multirow[b]{3}{*}{ Common name } & \multicolumn{2}{|l|}{ Fatty acid } & \multicolumn{5}{|c|}{ Proportion } \\
\hline & \multirow[b]{2}{*}{ Shorthand symbols* } & \multirow{2}{*}{$\begin{array}{c}\text { Relative retention } \\
\text { time on chromato- } \\
\text { gram } \ddagger\end{array}$} & \multicolumn{2}{|c|}{ American } & \multicolumn{2}{|c|}{ Japanese } & \multirow{2}{*}{$\begin{array}{l}\text { Difference in } \\
\text { means, (Ameri- } \\
\text { can minus Jap- } \\
\text { anese) }\end{array}$} \\
\hline & & & Mean & SD & Mean & SD & \\
\hline & & & $\%$ & $\%$ & $\%$ & $\%$ & \\
\hline Lauric & $12: 0$ & 0.32 & 0.41 & 0.24 & 0.24 & 0.11 & $+0.18 \S$ \\
\hline Myristic & $14: 0$ & 0.55 & 2.97 & 0.63 & 2.60 & 0.39 & $+0.38 \S$ \\
\hline \multirow[t]{3}{*}{ Myristoleic } & $14: 1$ & 0.70 & 0.48 & 0.19 & 0.42 & 0.13 & +0.06 \\
\hline & $15: 0$ & 0.75 & 0.34 & 0.17 & 0.23 & 0.07 & $+0.12 \S$ \\
\hline & $15: ?$ & 0.89 & 0.08 & 0.06 & 0.02 & 0.04 & $+0.06 \S$ \\
\hline Palmitic & $16: 0$ & 1.00 & 22.87 & 1.54 & 21.52 & 2.03 & $+1.35 \S$ \\
\hline \multirow[t]{3}{*}{ Palmitoleic } & $16: 1$ & 1.18 & 6.27 & 1.71 & 8.04 & 1.26 & $-1.77 \S$ \\
\hline & $17: 0$ & 1.36 & 0.61 & 0.15 & 0.59 & 0.13 & +0.02 \\
\hline & $16: 2 ?$ & 1.55 & 0.45 & 0.11 & 0.43 & 0.13 & +0.02 \\
\hline Stearic & $18: 0$ & 1.00 & 5.77 & 1.52 & 3.61 & 0.83 & $+2.16 \S$ \\
\hline Oleic & $18: 1$ & 1.15 & 48.23 & 1.78 & 42.96 & 2.75 & $+5.27 \S$ \\
\hline Linoleic & $18: 2$ & 1.40 & 10.21 & 1.91 & 16.48 & 3.04 & $-6.27 \S$ \\
\hline \multirow[t]{3}{*}{ Linolenic } & $18: 3$ & 1.85 & 0.58 & 0.21 & 0.97 & 0.37 & $-0.39 \S$ \\
\hline & $21: 0$ & 2.03 & 0.65 & 0.24 & 1.60 & 0.56 & $-0.95 \S$ \\
\hline & $?$ & 2.21 & 0.06 & 0.20 & 0.01 & 0.07 & +0.05 \\
\hline \multirow[t]{2}{*}{ Arachidonic } & $20: 4$ & 3.22 & $\operatorname{tr} \|$ & & $\operatorname{tr} \|$ & & \\
\hline & $?$ & 3.63 & $\operatorname{tr} \|$ & & $\operatorname{tr} \|$ & & \\
\hline
\end{tabular}

* In shorthand designation fatty acids are numbered according to number of carbon atoms per molecule (number before colon) and double bond content (number after colon).

$\ddagger$ Retention time relative to $16: 0$ if acid molecule contains less than 18 carbon atoms and relative to $18: 0$ if more than 18 carbon atoms.

$\S P<0.01$.

\| See text for explanation.

was determined from analysis of soybean oil. Quantitative analysis by gas chromatography was checked daily, before use, by analysis of a standard mixture consisting of known amounts of pure methyl esters of myristic, palmitic, and stearic acids (19). The response of the detector to the standard remained constant during the 7 wk course of analysis. For myristic acid the results of the average of duplicate daily analyses (mean $\pm_{\text {SEM }}$ ) of the 1 st 10 days and last 10 days of the course were $24.41 \pm 0.13$ and $24.25 \pm 0.12$ vs. a known composition of $24.39 \%$, for palmitic acid $11.06 \pm$ 0.03 and $11.01 \pm 0.05$ vs. $11.00 \%$, and for stearic acid $64.53 \pm$ 0.10 and $64.74 \pm 0.14$ vs. $64.61 \%$. In preliminary studies the recovery of pure arachidonic acid methyl ester was $98 \%$ complete. The analysis of each sample was completed within 3 days. The chromatograms of the duplicate samples of each specimen were performed the same day. Samples were analyzed in the randomized sequence, dscribed above, designed to minimize the possible effects of laboratory variation and bias. Specimens from the 18 extra subjects were analyzed in an order with intermixing by race. Judging acceptable agreement between analyses of duplicate tissue samples by criteria derived from a study of the components of variation in fatty acid measurements (16), analysis of three specimens had to be repeated.

The distribution of the proportions of fatty acids in both groups were determined for the 35-44 yr age range using 19 Japanese and 19 Americans. The distributions were plotted as the cumulative frequency of the percentages and were tested for significant group differences by the Kol-
gomorov-Smirnov test (20). The effects of age we observed to be significant in Americans over a broad range of years do not have a significant effect over the narrow range of age employed in this study of distributions. To test for associations between the proportions of acids in each group, the product moment correlation coefficients for the proportions of each possible pair of acids were computed for each of the decades of age, and combined by transforming each to zeta $\left[Z=\frac{1}{2} \log _{\bullet}(1+r) /(1-r)\right]$ and taking the weighted average. Some association is to be expected due to the constraint that the sum of the percentages of acids is 100 . The observed associations were evaluated as the excess of their combined coefficients over the values expected due to this constraint, i.e., the net coefficient (16). Computations were performed predominantly with an electronic computer.

\section{RESULTS}

Six fatty acids constituted about $95 \%$ of the fatty acid mixture in each group: myristic, palmitic, palmitoleic, stearic, oleic, and linoleic acids (Table III, ${ }^{\circ}$ ). Small

\footnotetext{
- The data on each subject has been deposited as Document 00353 with the ADI Auxiliary Publications Project, Photoduplication Service, Library of Congress, Washington 25, D. C. A copy may be secured by citing the Document number and be remitting $\$ 1.25$ for photoprints, or $\$ 1.25$ for 35 $\mathrm{mm}$ microfilm. Advance payment is required. Make checks or money orders payable to: Chief, Photoduplication Service, Library of Congress.
} 

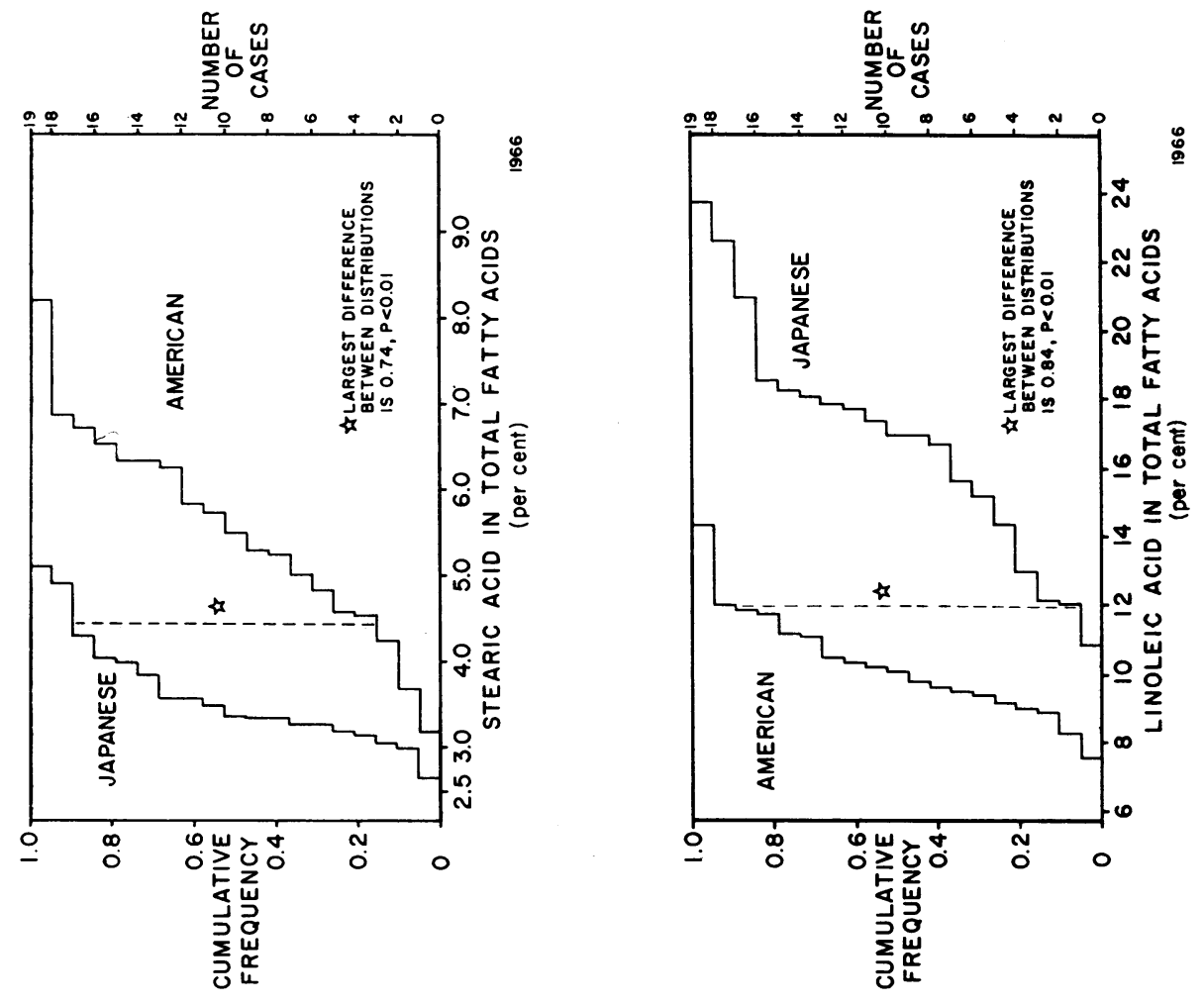

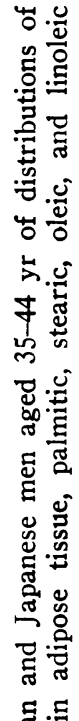
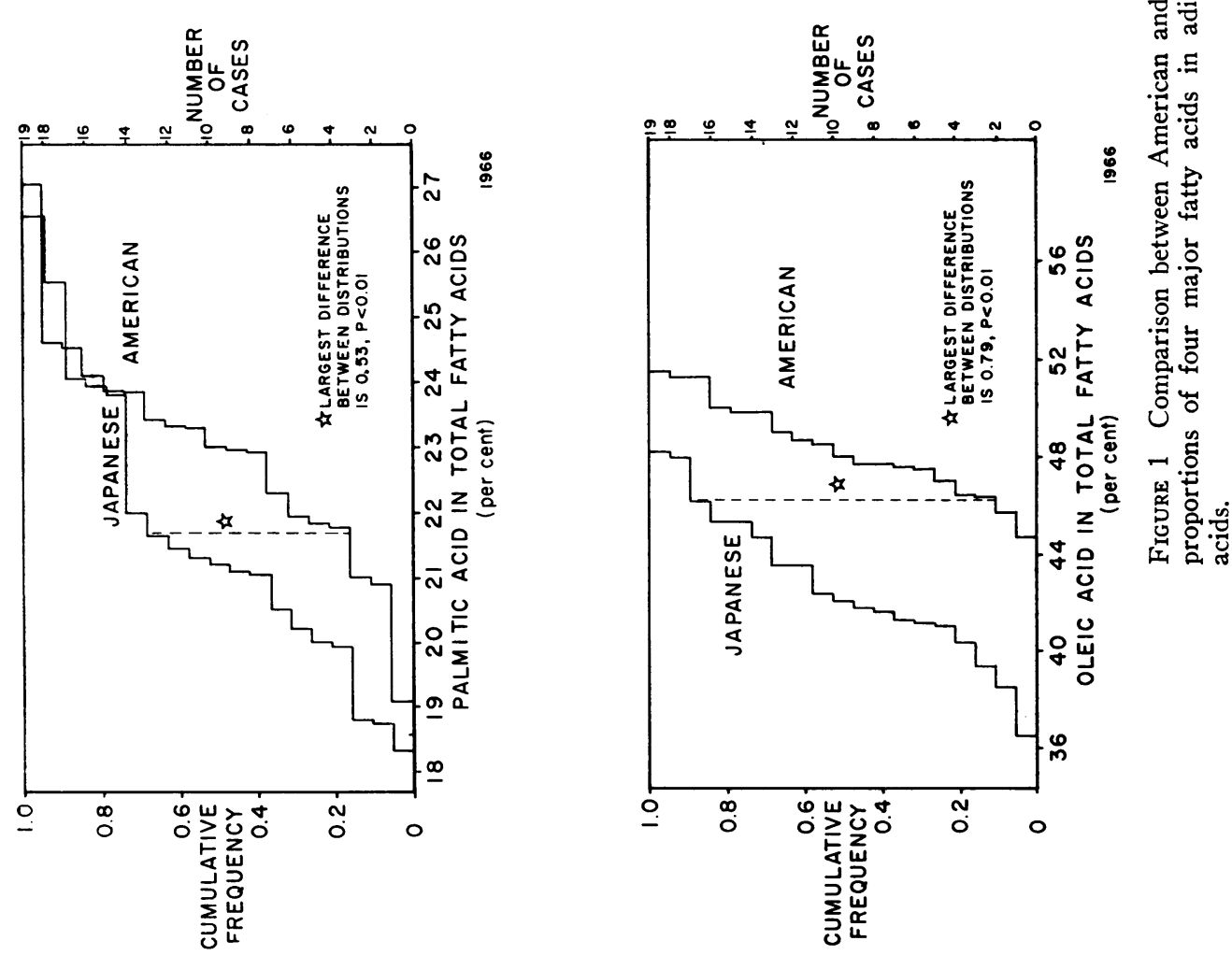

Fatty Acid Composition of Adipose Tissue of Japanese and American Men 
TABLE IV

Coefficient of Correlation between Proportions of Major Fatty Acids of Adipose Tissue and Age

\begin{tabular}{|c|c|c|c|c|c|c|c|c|c|}
\hline \multirow[b]{2}{*}{ Group } & \multirow{2}{*}{$\begin{array}{l}\text { No. of } \\
\text { subjects }\end{array}$} & \multirow[b]{2}{*}{ Age, average \pm SD } & \multicolumn{7}{|c|}{ Fatty acid } \\
\hline & & & $12: 0$ & $14: 0$ & $16: 0$ & $16: 1$ & $18: 0$ & $18: 1$ & $18: 2$ \\
\hline & & $y r$ & & & & & & & \\
\hline American & 50 & $39.1 \pm 12.0$ & $-0.61^{*}$ & $-0.30 \ddagger$ & +0.23 & $+0.47^{*}$ & $-0.43^{*}$ & $+0.39^{*}$ & $-0.45^{*}$ \\
\hline Japanese & 56 & $41.0 \pm 12.6$ & -0.06 & +0.09 & -0.16 & +0.23 & -0.24 & +0.06 & -0.05 \\
\hline
\end{tabular}

$* P<0.01$

$\ddagger P<0.05$.

proportions of 11 other minor acids, some of which could be tentatively identified, were also observed. Highly significant differences occurred between Americans and Japanese in the average proportions of many of the acids (Table III). Americans had higher proportions of lauric, myristic, palmitic, stearic, and oleic acids than did the Japanese; Japanese had higher proportions of palmitoleic and linoleic acids. Among the minor fatty acids Japanese had more linolenic acid. Arachidonic acid and the acid with a retention volume of 3.63 relative to $18: 0$ were present inconsistently and usually in amounts too small to be quantitated by routine chromatography; they were considered to be present in a specimen if detected in both samples. On this basis arachidonic acid was detected in trace amounts in $48 \%$ of Americans and $57 \%$ of Japanese. However, chromatography of large aliquots showed it to be present in each of five Americans and five Japanese, selected at random, in amounts ranging from 0.28 to $0.48 \%$ and 0.18 to $0.51 \%$, respectively. The fatty acid with a relative retention volume of 3.63 was detected during routine analysis in $12 \%$ of Americans in amounts too small to be quantitated and in $67 \%$ of the Japanese; in 12 Japanese it averaged $1.2 \%$ of the total fatty acids. More accurate analysis by chromatography of large aliquots showed its presence in one of five Americans at $0.25 \%$ of total acids and in each of five Japanese at $0.39-0.89 \%$ of total acids. This acid is tentatively identified as a 20 - to 24-carbon atom, unsaturated acid, based on its retention volume and failure to chromatograph

after bromination. The acid with a retention volume of 1.22 relative to palmitic acid noted in our previous study was not detected in the present specimens. The differences between Japanese and Americans were not related to the race of the Americans. Highly significant differences $(P<0.01)$ occurred between Japanese and Caucasian Americans with lauric, myristic, palmitic, palmitoleic, stearic, oleic, and linoleic acids and between Japanese and Negro Americans with the same acids except for myristic and palmitic acids. The differences between Caucasians and Negroes observed in this study are similar in sign and size to those we reported earlier (16), except that only the difference with stearic acid was significant $(P<0.01)$.

Study of the distribution of proportions of the major fatty acids in middle-aged subjects show further differences between Japanese and Americans (Fig. 1). The distributions of palmitic acid were significantly different, $P<0.01$, probably due to the moderate positive skewness of the Japanese (distribution curve tails asymmetrically to the right due to individuals with high values of palmitic acid) and the small difference in location of the means. With stearic acid the difference appeared due to the Americans' higher mean proportion and greater dispersion. Although most Americans had values in a range above that of the Japanese a few Americans had proportions similar to the lower range for the Japanese. Oleic acid differed in the means and greater dispersion of the Japanese. For linoleic acid the means were different and Japanese had a wider dis-

TABLE V

Coefficients of Correlation between Proportions of Major Fatty Acids and Percentage of Standard Body Weight

\begin{tabular}{|c|c|c|c|c|c|c|c|c|c|}
\hline \multirow[b]{2}{*}{ Group } & \multirow{2}{*}{$\begin{array}{l}\text { No. of } \\
\text { subjects }\end{array}$} & \multirow{2}{*}{$\begin{array}{l}\text { Percentage of } \\
\text { standard body wt, } \\
\text { average } \pm \text { SD }\end{array}$} & \multicolumn{7}{|c|}{ Fatty acid } \\
\hline & & & $12: 0$ & $14: 0$ & $16: 0$ & $16: 1$ & $18: 0$ & $18: 1$ & $18: 2$ \\
\hline & & $\%$ & & & & & & & \\
\hline American & 50 & $102.6 \pm 17.4$ & $-0.37^{*}$ & -0.22 & $+0.40^{*}$ & +0.11 & $-0.56^{*}$ & +0.14 & +0.05 \\
\hline Japanese & $49 \ddagger$ & $103.8 \pm 12.5$ & -0.12 & $-0.37^{*}$ & +0.07 & +0.14 & -0.21 & +0.10 & +0.02 \\
\hline
\end{tabular}

$* P<0.01$.

$\ddagger$ Body weights of seven subjects not available.

1318 W. Insull, Jr., P. D. Lang, B. P. Hsi, and S. Yoshimura 
persion. Palmitoleic acid differed due to location of the means; both distributions were symmetrical with equal dispersions. The distributions of lauric and myristic acids were not different. Lauric acid in both appeared to have a normal distribution. The myristic acid distribution in Americans had a slight positive skewness.

No significant correlations between age and fatty acid composition occurred among the Japanese, while among Americans there were significant decreases in lauric, myristic, stearic, and linoleic acids, and significant in-
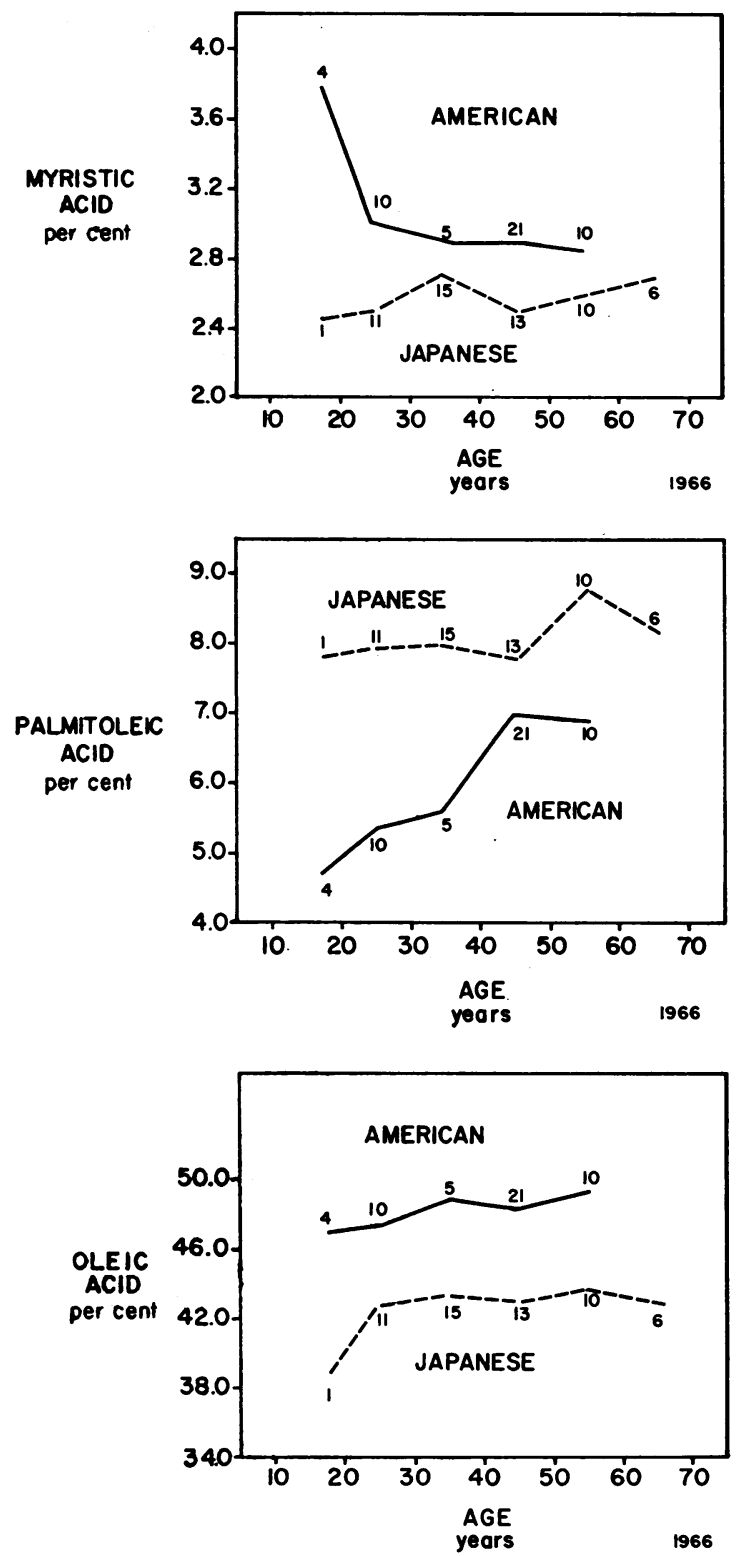

creases in palmitoleic and oleic acids as age increased (Table IV and Fig. 2). Palmitic acid proportions were not correlated with age.

The percentage of standard body weight correlated with the proportions of some fatty acids (Table V). With increasing body weight in Americans, palmitic acid increased, and lauric and stearic acids decreased In Japanese myristic acid decreased.

The correlation coefficients between the percentages of the major acids, the coefficients expected from the
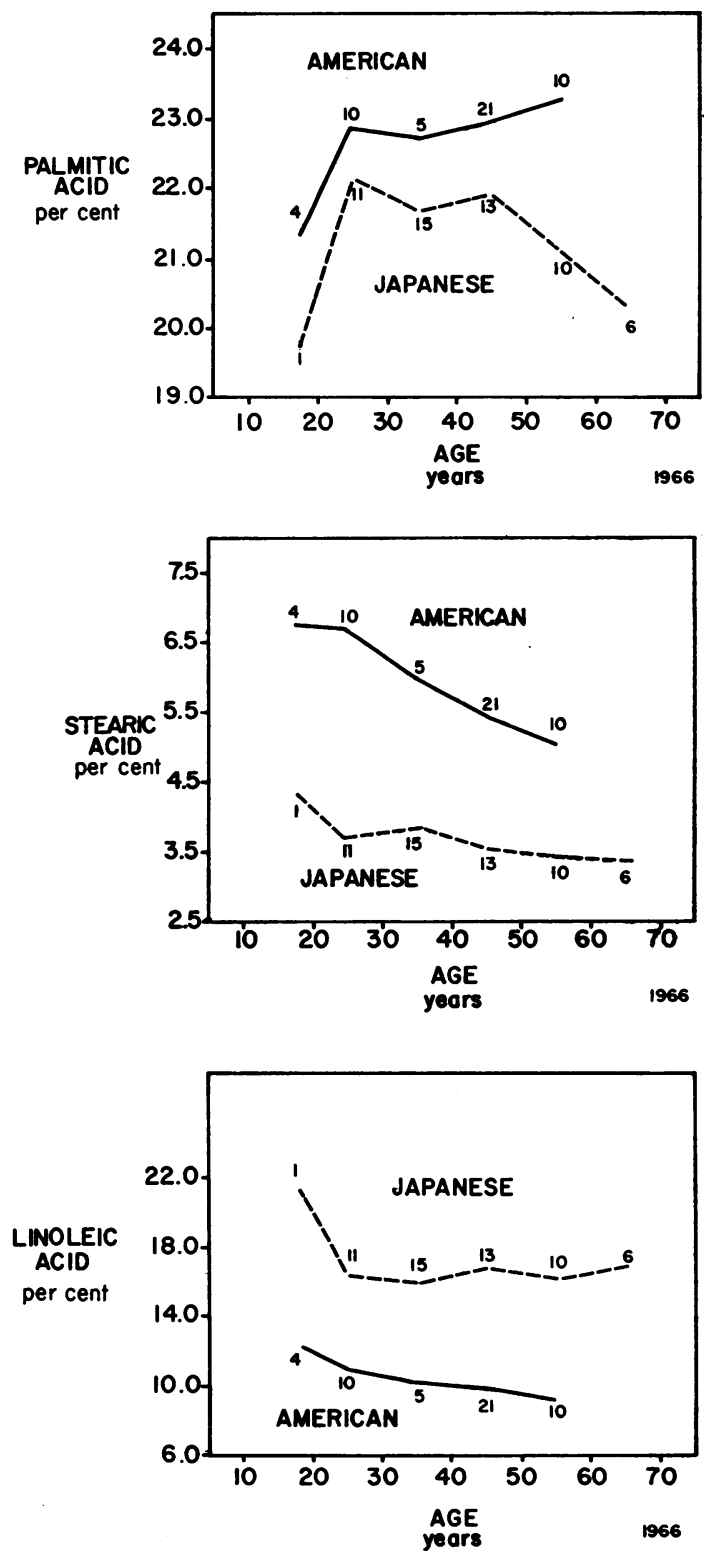

FIGURE 2 Relationships between age and mean proportion of major fatty acids in adipose tissues of Americans and Japanese. Number of subjects in each decade are noted along the curves. 
constraint that the sum of the percentages of the acids is 100 , and the net correlation coefficients are given in Tables VI (Americans) and VII (Japanese). Significant net correlations, $P<0.01$, were observed in both groups. While both groups had significant net correlations between the same four pairs of acids, each group also had a number of unique correlations. Both showed significant positive correlations between lauric and myristic, myristic and myristoleic, and myristoleic and palmitoleic acid. Both had a significant negative correlation between palmitoleic and stearic acid. Americans had seven unique correlations: five negative, lauric and oleic, myristic and oleic, myristoleic and stearic, myristoleic and linoleic, and palmitoleic and linoleic, and two positive, lauric and myristoleic, and palmitoleic and oleic. Japanese had three unique correlations: one negative, oleic and linoleic, and two positive, palmitic and palmitoleic, and palmitic and oleic. In Japanese, five

\section{TABLE VI}

Coefficients of Correlation between the Proportions of Major Fatty Acids of Adipose Tissue of American Men

\begin{tabular}{|c|c|c|c|}
\hline Fatty Acids & $\begin{array}{l}\text { Observed } \\
\text { coefficient }\end{array}$ & $\begin{array}{l}\text { Expected } \\
\text { coefficient }\end{array}$ & $\begin{array}{c}\text { Net* } \\
\text { coefficient }\end{array}$ \\
\hline $12: 0 \& 14: 0$ & 0.804 & -0.011 & $0.807 \ddagger$ \\
\hline $12: 0 \& 14: 1$ & 0.564 & -0.004 & $-0.567 \ddagger$ \\
\hline $12: 0 \& 16: 0$ & -0.170 & -0.033 & $-0.137^{+}$ \\
\hline $12: 0 \& 16: 1$ & 0.054 & -0.016 & 0.068 \\
\hline $12: 0 \& 18: 0$ & 0.079 & -0.015 & -0.091 \\
\hline $12: 0 \& 18: 1$ & -0.477 & -0.059 & $-0.431 \ddagger$ \\
\hline $12: 0 \& 18: 2$ & -0.166 & -0.020 & -0.147 \\
\hline $14: 0 \& 14: 1$ & 0.775 & -0.012 & $0.779 \ddagger$ \\
\hline $14: 0 \& 16: 0$ & -0.019 & -0.095 & $0.076^{+}$ \\
\hline $14: 0 \& 16: 1$ & 0.156 & -0.045 & 0.199 \\
\hline $14: 0 \& 18: 0$ & -0.071 & -0.043 & -0.028 \\
\hline $14: 0 \& 18: 1$ & -0.571 & -0.168 & $-0.446 \ddagger$ \\
\hline $14: 0 \& 18: 2$ & -0.332 & -0.058 & -0.279 \\
\hline $14: 1 \& 16: 0$ & 0.005 & -0.038 & +0.041 \\
\hline $14: 1 \& 16: 1$ & 0.549 & -0.018 & $+0.561 \ddagger$ \\
\hline $14: 1 \& 18: 0$ & -0.503 & -0.017 & $-0.491 \ddagger$ \\
\hline $14: 1 \& 18: 1$ & -0.184 & -0.067 & -0.118 \\
\hline $14: 1 \& 18: 2$ & -0.478 & -0.023 & $-0.458 \ddagger$ \\
\hline $16: 0 \& 16: 1$ & -0.183 & -0.143 & -0.041 \\
\hline $16: 0 \& 18: 0$ & -0.078 & -0.134 & +0.056 \\
\hline $16: 0 \& 18: 1$ & -0.447 & -0.528 & +0.104 \\
\hline $16: 0 \& 18: 2$ & -0.216 & -0.182 & -0.035 \\
\hline $16: 1 \& 18: 0$ & -0.602 & -0.064 & $-0.558 \ddagger$ \\
\hline $16: 1 \& 18: 1$ & 0.388 & -0.254 & $+0.583 \ddagger$ \\
\hline $16: 1 \& 18: 2$ & -0.696 & -0.087 & $-0.647 \ddagger$ \\
\hline $18: 0 \& 18: 1$ & -0.268 & -0.237 & -0.033 \\
\hline $18: 0 \& 18: 2$ & 0.093 & -0.082 & +0.174 \\
\hline $18: 1 \& 18: 2$ & -0.278 & -0.323 & +0.049 \\
\hline
\end{tabular}

* Net coefficient determined from the difference between the observed coefficient and the expected coefficient using the transformation of coefficients to zeta equivalents (16). $\ddagger P<0.01$.
TABLE VII

Coefficients of Correlation between the Proportion of Major Fatty Acids of Adipose Tissue of Japanese Men

\begin{tabular}{|c|c|c|c|}
\hline Fatty Acids & $\begin{array}{l}\text { Observed } \\
\text { coefficient }\end{array}$ & $\begin{array}{l}\text { Expected } \\
\text { coefficient }\end{array}$ & $\begin{array}{c}\text { Net* } \\
\text { coefficient }\end{array}$ \\
\hline $12: 0 \& 14: 0$ & 0.520 & -0.008 & $0.524 \ddagger$ \\
\hline $12: 0 \& 14: 1$ & 0.141 & -0.003 & 0.143 \\
\hline $12: 0 \& 16: 0$ & -0.147 & -0.025 & -0.122 \\
\hline $12: 0 \& 16: 1$ & -0.374 & -0.014 & $-0.362 \S$ \\
\hline $12: 0 \& 18: 0$ & 0.361 & -0.009 & $0.368 \S$ \\
\hline $12: 0 \& 18: 1$ & -0.175 & -0.042 & -0.135 \\
\hline $12: 0 \& 18: 2$ & 0.147 & -0.021 & 0.168 \\
\hline $14: 0 \& 14: 1$ & 0.577 & -0.011 & $0.584 \ddagger$ \\
\hline $14: 0 \& 16: 0$ & 0.139 & -0.086 & 0.221 \\
\hline $14: 0 \& 16: 1$ & 0.168 & -0.048 & 0.215 \\
\hline $14: 0 \& 18: 0$ & 0.325 & -0.032 & $0.353 \S$ \\
\hline $14: 0 \& 18: 1$ & -0.218 & -0.142 & $-0.078^{\circ}$ \\
\hline $14: 0 \& 18: 2$ & -0.235 & -0.072 & -0.165 \\
\hline $14: 1 \& 16: 0$ & -0.034 & -0.034 & 0.067 \\
\hline $14: 1 \& 16: 1$ & 0.545 & -0.019 & $0.558 \ddagger$ \\
\hline $14: 1 \& 18: 0$ & -0.250 & -0.013 & -0.238 \\
\hline $14: 1 \& 18: 1$ & -0.189 & -0.056 & -0.134 \\
\hline $14: 1 \& 18: 2$ & -0.201 & -0.029 & -0.173 \\
\hline $16: 0 \& 16: 1$ & 0.366 & -0.155 & $0.493 \ddagger$ \\
\hline $16: 0 \& 18: 0$ & -0.158 & -0.102 & -0.058 \\
\hline $16: 0 \& 18: 1$ & -0.069 & -0.457 & $+0.400 \ddagger$ \\
\hline $16: 0 \& 18: 2$ & -0.562 & -0.232 & $-0.380 \S$ \\
\hline $16: 1 \& 18: 0$ & -0.573 & -0.057 & $-0.533 \ddagger$ \\
\hline $16: 1 \& 18: 1$ & -0.040 & -0.257 & 0.220 \\
\hline $16: 1 \& 18: 2$ & -0.429 & -0.131 & $-0.316 \S$ \\
\hline $18: 0 \& 18: 1$ & 0.129 & -0.168 & $0.290^{\circ}$ \\
\hline $18: 0 \& 18: 2$ & -0.078 & -0.086 & 0.007 \\
\hline $18: 1 \& 18: 2$ & -0.675 & -0.385 & $-0.392 \ddagger$ \\
\hline
\end{tabular}

* Net coefficient determined from the differences between the observed coefficient and the expected coefficient using the transformation of coefficients to zeta equivalents (16).

$\ddagger P<0.01$.

$\S P<0.05$.

additional correlations significant at $P<0.05$ were also observed. There were no differences between groups in the signs of any significant correlations.

\section{DISCUSSION}

This study was designed as a detailed comparison of the fatty acid composition of adipose tissue of Japanese and American men to define differences in fatty acid metabolism potentially associated with the differences between the countries in the incidence of arteriosclerosis. Tissues, collected in each population from closely agematched contemporary subjects who had had similar states of health before death, were stored in a comparable manner and analyzed in the same laboratory in a random sequence of matched pairs. The cholesterol contents of adipose tissue from the two groups were not significantly different, and agreed with published values (18), indi- 
cating that the gross lipid compositions of their tissues were normal and comparable. The low content of cholesterol with the expected low proportion of cholesterol esters and proportionally low concentration of phospholipid (21) would not contribute significantly to the total fatty acids in adipose tissue measured in this study. Hence these fatty acid analyses can be regarded as representative of the fatty acids of adipose glycerides. The quality of the gas chromatographic analyses was carefully validated and monitored. The fatty acid composition of adipose tissue in our Japanese and American men resembled those reported in earlier studies (Table VIII), indicating that the subjects of our groups were probably not different from those of other studies and that each group may be representative of its national population. The differences observed between Caucasian and Negro Americans for the major fatty acids are generally smaller than those observed here between Japanese and the American group comprised of Caucasians and $\mathrm{Ne}$ groes (16). The differences between Japanese and
Caucasian Americans, and between Japanese and $\mathrm{Ne}$ gro Americans are similar to those between Japanese and the grouped Americans.

Significant differences between Japanese and Americans occurred with each relationship of the proportions of fatty acids we examined: the mean proportions of fatty acids, the distribution of proportions, the correlations of fatty acid proportions with age and body weight, and the patterns of interacid correlations.

The mean proportions of all major and many minor acids were significantly different between the groups in spite of the effects of increasing age in Americans to reduce some differences. In the only published comparison between Japanese and American adipose tissue, Hegsted, Jack, and Stare observed differences, some of which we calculate to be significant, similar to those we report here (26). In their data Japanese proportions were lower for stearic and oleic acids, and higher for palmitoleic, all with $P<0.01$. The sources of their study populations were not described in detail.

T.ABLE VIII

Proportions of Major Fatty Acids of Adipose Tissue from Americans and Japanese Reported by Various Studies

\begin{tabular}{|c|c|c|c|c|c|c|c|c|c|}
\hline \multirow[b]{2}{*}{ Nationality and study } & \multirow{2}{*}{$\begin{array}{l}\text { Total No. } \\
\text { subjects }\end{array}$} & \multicolumn{2}{|c|}{$\begin{array}{l}\text { No. of subjects } \\
\text { by sex }\end{array}$} & \multicolumn{6}{|c|}{ Per cent fatty acid } \\
\hline & & $\sigma^{\pi}$ & \& & $14: 0$ & $16: 0$ & $16: 1$ & $18: 0$ & $18: 1$ & $18: 2$ \\
\hline \multicolumn{10}{|l|}{ Americans } \\
\hline Hirsch et al. (22) & 12 & 7 & 5 & 3.3 & 19.5 & 6.9 & 4.2 & 46.7 & 11.4 \\
\hline Gelhorn and Marks (23) & 9 & \multicolumn{2}{|c|}{ no data } & 2.4 & 24.6 & 5.6 & 6.0 & 49.9 & 9.5 \\
\hline Dabney (24) & 10 & 2 & 8 & 3.0 & 20.8 & 6.1 & 8.3 & 44.0 & 14.5 \\
\hline Scott et al. (25) & 57 & 28 & 29 & 3.8 & 24.1 & 6.5 & 4.0 & 51.6 & 7.5 \\
\hline Hegsted, Jack and Stare (26) & 17 & \multicolumn{2}{|c|}{ no data } & 3.6 & 24.6 & 6.1 & 6.7 & 50.3 & 7.9 \\
\hline Dayton et al. (27) & 75 & 75 & & 2 & 21 & 7 & 6 & 52 & 9 \\
\hline \multirow{2}{*}{ Lee et al. (28) } & 55 & 25 & 30 & 2.1 & 21.4 & 7.7 & 2.9 & 53.8 & 12.1 \\
\hline & $55^{*}$ & 20 & 35 & 1.9 & 23.3 & 5.9 & 4.1 & 53.6 & 11.2 \\
\hline Sweeney et al. (29) & 10 & & 10 & 2.9 & 23.4 & 6.7 & 4.4 & 50.7 & 10.6 \\
\hline Remenchik and Bernsohn (30) & $26 \ddagger$ & \multicolumn{2}{|l|}{26} & 2.9 & 24.1 & 7.4 & 5.2 & 49.9 & 7.3 \\
\hline Scott et al. (31) & 19 & \multicolumn{2}{|l|}{19} & 3.2 & 23 & 7.2 & 4.1 & 53 & 8.9 \\
\hline Christakis et al. (32) & 78 & 78 & & 2.0 & 23.7 & 5.8 & 3.8 & 53.2 & 9.7 \\
\hline \multirow[t]{2}{*}{ Insull and Bartsch (16) } & 56 & 28 & 28 & 2.9 & 22.4 & 5.8 & 6.0 & 49.9 & 9.5 \\
\hline & $51^{*}$ & 27 & 24 & 2.6 & 23.0 & 4.9 & 8.0 & 49.8 & 8.9 \\
\hline Present study & 50 & \multicolumn{2}{|l|}{50} & 3.0 & 22.9 & 6.3 & 5.8 & 48.2 & 10.2 \\
\hline \multicolumn{10}{|l|}{ Japanese } \\
\hline Hegsted, Jack and Stare (26) & 27 & \multicolumn{2}{|c|}{ no data } & 3.4 & 24.9 & 10.5 & 4.8 & 40.6 & 9.4 \\
\hline Goto and Nakamura (33) & 14 & \multicolumn{2}{|c|}{ no data } & 3.2 & 26.1 & 6.4 & 4.0 & 46.1 & 12.5 \\
\hline Cooperative study $\S$ & 118 & 67 & 51 & 3.6 & 23.6 & 9.0 & 4.2 & 42.5 & 16.8 \\
\hline Imaichi et al. (34) & 6 & \multicolumn{2}{|l|}{6} & 2.7 & 19.0 & 8.7 & 3.5 & 42.6 & 12.8 \\
\hline Kumagai and Fujimoto (35) & 5 & \multirow{2}{*}{\multicolumn{2}{|c|}{56}} & 2.5 & 20.7 & 10.9 & 2.6 & 43.0 & 13.4 \\
\hline Present study & 56 & & & 2.6 & 21.5 & 8.0 & 3.6 & 43.0 & 16.5 \\
\hline
\end{tabular}

* Negro.

$\ddagger$ Nonobese subjects only.

\$izawa, T., Y. Nakao, K. Oshima, S. Aoyama, M. Nishikawa, Y. Yamamura, T. Yoshida, N. Kimura, S. Miyao, H. Nagai, T. Takai, K. Yamakawa, T. Yamakawa, H. Miyake, and Y. Imai. 1967. Cooperative study of fatty acid composition in serum and adipose tissue in Japanese by gas chromatography. Personal communication. 
The analysis of the distribution of proportions of fatty acids in the two populations showed significant differences for palmitic, palmitoleic, stearic, oleic, and linoleic acids. These differences occurred variously with three characteristics of distribution: mean proportion, skewness, and dispersion. The biochemical interpretation of differences in skewness and dispersion are matters of speculation at present. In Japanese the moderate positive skewness of palmitic acid values could be due to the presence in our study population of two or more groups with different palmitic acid values, or due to the control of proportions of palmitic acid by many factors of approximately equal power. The wider dispersion of values of linoleic acid in Japanese, and of stearic acid in Americans might depend upon the opportunities for broader ranges of dietary intake of these acids. In comparing diets of the groups the Japanese have a higher proportion of linoleic acid whereas the Americans have a higher proportion of stearic acid. In both groups the proportion of these acids in the diet fats exceeds the proportion in the adipose fats (Table $\mathrm{X}$ ). The analysis of the distributions of adipose fatty acids in a single population or in a comparison of different populations has not been reported before.

Significant correlations between age and the proportion of certain fatty acids appear to be a true characteristic of Americans but not Japanese (Table IX). It is demonstrable in Americans if the examination covers most of the adult range of age, from the 20's through the 50's. With increasing age, decreasing proportions occur with lauric, myristic, stearic, and apparently linoleic acids, while increasing proportions occur with oleic and possibly palmitoleic acids. Although a significant relationship between palmitic acid and age was observed in a previous study (16), it was not seen in the present study probably because the older ages were not covered. Since the analysis is made on successive cohorts of Americans the changes with age could be due to genetically determined cohort differences, or, more likely due to differences in choices of diet. The fact that the Japanese show no changes with age means that changing composition of adipose fatty acids is not an essential accompaniment of the ageing process.

Significant correlation between the per cent of standard body weight and the proportions of certain fatty acids appear to be present for Americans whereas Japanese show a correlation with only one acid, myristic. In Americans the positive correlation with palmitic acid in the present study is consistent with the correlation between skin fold thickness and palmitic acid reported previously (36). Negative correlations occurred with lauric, myristic, and stearic acids $(16,36)$. These differences between the races may reflect differences in availability of the acids. The correlation between palmitic acid and body weight in the present study was not seen in our study covering older ages (16) possibly due to the decrease of the proportions of palmitic acid with age in the older groups.

The significant associations between proportions of the major fatty acids within each group are summarized in Fig. 3. Here each fatty acid is represented by a circle whose area is proportional to the acid's percentage of the total fatty acids. Significant correlations between acids are indicated by a continuous line when $P<0.01$ and by a dashed line when $P<0.05$. The sign of the correlation is denoted by an adjacent plus or minus symbol. Comparison of the interacid correlations $(P<0.01)$ of the two groups shows that four significant correlations are common to both groups, seven others occur only in Americans, and another three occur only in Japanese. With this presentation the groups are readily seen to be different, each having a unique pattern of significant associations. The pattern of correlations for the Americans is closely similar to that observed in earlier studies and agrees with the few observations in the literature (16). The literature contains no reports on interacid correlations of Japanese or interracial comparisons of interacid correlations. These considerations and

TABLE IX

Coefficients of Correlation between Age and Proportions of Major Fatty Acids of Adipose Tissue

\begin{tabular}{|c|c|c|c|c|c|c|c|c|c|}
\hline \multirow[b]{2}{*}{ Nationality and study } & \multirow[b]{2}{*}{$\begin{array}{l}\text { No. of subjects } \\
\text { and sex }\end{array}$} & \multirow[b]{2}{*}{$\begin{array}{l}\text { Age, average } \\
\quad \pm S D\end{array}$} & \multicolumn{7}{|c|}{ Fatty acid } \\
\hline & & & $12: 0$ & $14: 0$ & $16: 0$ & $16: 1$ & $18: 0$ & $18: 1$ & $18: 2$ \\
\hline \multicolumn{10}{|l|}{ American } \\
\hline $\begin{array}{l}\text { Scott et al. (25) } \\
\text { Insull and Bartsch (16) } \\
\text { Insull, Houser, and Littell (36) } \\
\text { Present study }\end{array}$ & $\begin{array}{l}57, M \text { and } F \\
107, M \text { and } F \\
59, M \text { and } F \\
50, M\end{array}$ & $\begin{array}{l}62.8 \pm 15.3 \\
44.2 \pm 19.2 \\
43.6 \pm 8.8 \\
39.1 \pm 12.0\end{array}$ & $\begin{array}{l}-0.12 \\
-0.21 t \\
-0.15 \\
-0.618\end{array}$ & $\begin{array}{l}-0.11 \\
-0.19 \ddagger \\
-0.13 \\
-0.30 \ddagger\end{array}$ & $\begin{array}{r}-0.28 \\
-0.01 \\
+0.15 \\
+0.23\end{array}$ & $\begin{array}{l}-0.04 \\
+0.12 \\
-0.19 \\
+0.478\end{array}$ & $\begin{array}{l}+0.17 \\
-0.17 \ddagger \\
-0.25 \ddagger \\
-0.438\end{array}$ & $\begin{array}{l}+0.28 \\
+0.268 \\
+0.17 \\
+0.398\end{array}$ & $\begin{array}{l}-0.11 \\
-0.16 \\
-0.12 \\
-0.458\end{array}$ \\
\hline \multicolumn{10}{|l|}{ Japanese } \\
\hline Present study & 56. M & $41.0 \pm 12.6$ & -0.06 & +0.09 & -0.16 & +0.23 & -0.24 & +0.06 & -0.05 \\
\hline
\end{tabular}

$* \mathbf{M}=$ male, $\mathbf{F}=$ female.

$\ddagger P<0.05$.

$\& P<0.01$. 
those immediately following indicate that patterns of interacid correlations may be stable characteristics useful in comparing populations and in investigating their fatty acid metabolism.

The present data on the group differences of interacid correlations are the first to provide a basis for proposing realistic interpretations of the interacid correlations in man. These relationships among fatty acids of adipose tissue, and how the relationships may be different with differences in diets and incidence of arteriosclerosis have not been studied, although an understanding of them may provide insight into the fatty acid metabolism associated with this disease. In general, the interacid correlations may be viewed as indicating the major currents within the total complex of fatty acid metabolism of the whole body (the coordination of synthesis, interacid conversion, and catabolism) and the effects of exogenous dietary acids. The correlations may be due to the unique action of specific acids or the impression by the mass action of fatty acids dominating the supply of acids. As Japanese and American adipose tissues present some opposite extremes of fatty acid composition they may also present the extreme values of interacid correlations. The correlations common to both groups may represent the interacid relationships that are firmly fixed in all men; in contrast, correlations exclusively in one group or the other may represent interacid relationships that are alterable. Study of the circumstances associated with these two types of correlations may provide some understanding of them. The persistent absence of a correlation

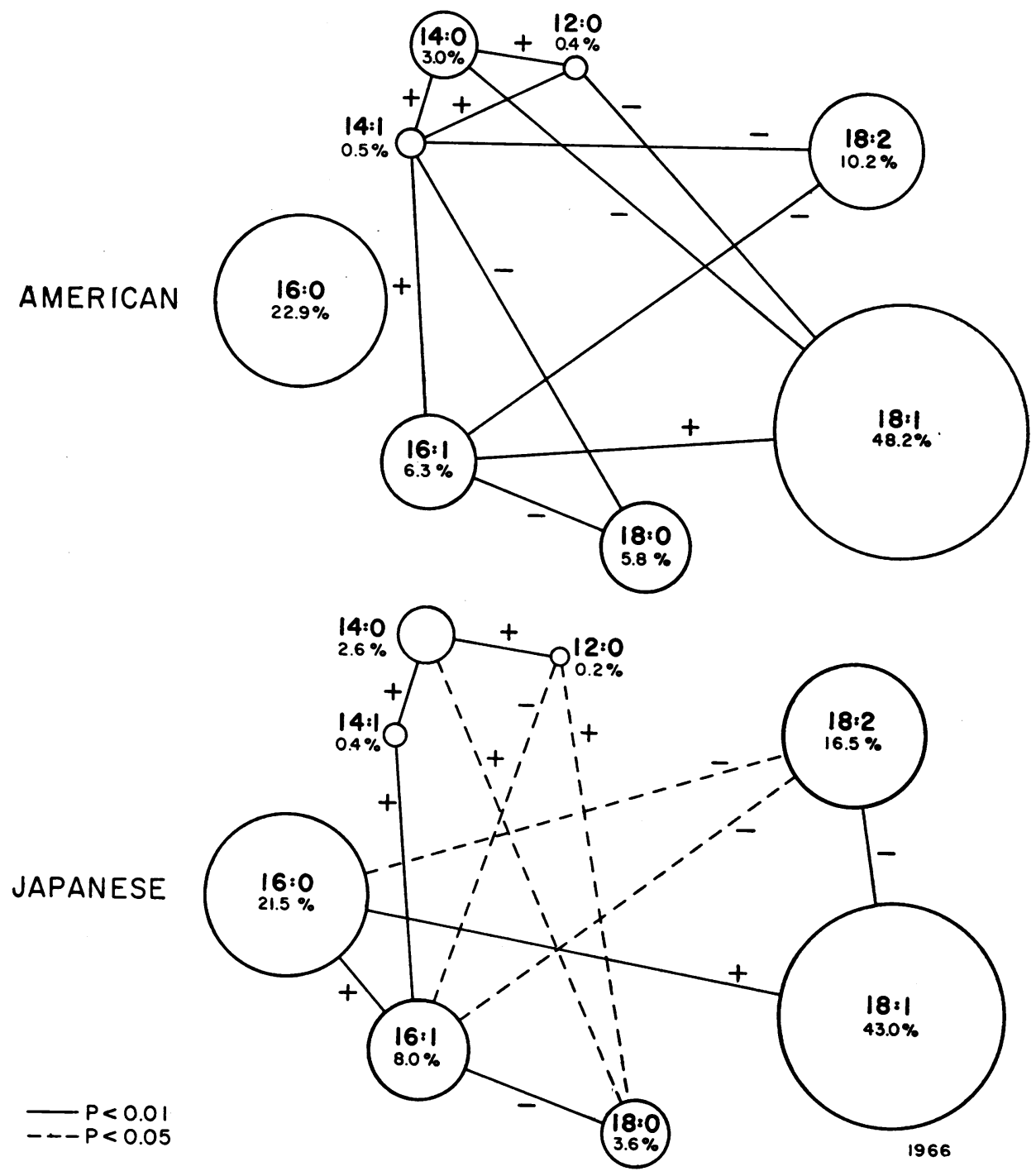

FIGURE 3 Proportions of major fatty acids and the pattern of their associations in adipose tissue of American and Japanese men. (See discussion in text for explanation). 
may identify acids that have no common or closely similar metabolic mechanisms. With these precepts we propose that the correlations common to Japanese and Americans with $P<0.01$ may represent closely restricted relationships between two acids, possibly by linking of enzymic processes. However, these interpretations must be viewed cautiously as they are based on measurements of mass of acids without consideration of their flux, and use simple concepts of metabolism and of the influence of obvious factors.

With the correlations common to both groups, for example, the positive correlations between lauric and myristic may represent the close linking of the synthesis of the two major saturated acids with carbon chains shorter than palmitic acid, the major stem acid. Similarly the positive correlation between myristoleic and palmitoleic acids may represent close linking of the synthesis of shorter chain monoene acids. The positive correlation between myristic and myristoleic may represent a precursor-product relationship. The negative correlation between palmitoleic and stearic acid may represent their competition for palmitic acid as a common precursor.

The group-specific correlations, with $P<0.01$, may represent alterable, rather loose relationships dependent not primarily upon common or closely similar enzymic mechanisms, but upon general effects, as that of mass action. The effects of diet by introducing a fatty acid mass of fixed composition, large or small relative to the body's content, may be the dominant influence here since this is the most evident difference between Japanese and Americans. The smaller proportion of fat and the higher proportion of carbohydrate in the Japanese diet may provoke more active endogenous synthesis of certain fatty acids in Japanese. For correlations unique to Americans we hypothesize that the positive correlation of palmitoleic-oleic represents imposition of the fatty acid pattern of the diet fat or the effects of stimulation of syn- thesis of longer chain monoene acids. The negative correlations of lauric and myristic with oleic acid could be due to dilution of the shorter chain acids by the dominant mass of oleic in the diet. The negative correlations of myristoleic and palmitoleic with the essential acid linoleic could be due to unique effects of linoleic on their synthesis, or more simply the diluting effect of this prominent diet acid. For correlations unique to Japanese we propose that the positive palmitic-oleic and palmitic-palmitoleic correlations could be relationships between the major products of a common synthetic mechanism. The negative correlation between oleic and linoleic acids could represent a reciprocal relationship determined by the fatty acid pattern of the diet.

The most important factor influencing adipose fatty acid composition appears to be diet. That changes in diet can alter adipose composition, and that unusual dietary intakes are associated with extreme values of adipose has been observed only recently in man although it has long been known in animals (37). The composition of adipose in Americans can be greatly altered toward that of individuals on a largely vegetarian diet and may ultimately obtain linoleic acid proportions exceeding that generally reported for vegetarian diets (38). The alterability of adipose fatty acid composition is characteristic of all race groups and not limited to Caucasians, as it has been seen in Koreans whose vegetarian pattern of adipose acids can be changed toward the American pattern by eating an American diet (31). The relatively high proportion of oleic acid seen in Americans is not near the maximum, as it is greatly exceeded in Cretans whose average of $61.9 \%$ is due to diets rich in oleic acid from olive oil (39).

Knowledge of the relationships of the diets to adipose composition in our subjects is limited, owing to lack of diet information on individual subjects. As a substitute, comparison with the estimated fatty acid composition of

TABLE $\mathrm{X}$

Comparison of Proportion of Major Fatty Acids in the Diets of the American and Japanese Populations and of Adipose Tissues of Men in Present Study

\begin{tabular}{llllllllll}
\hline \multirow{2}{*}{ Nationality } & \multicolumn{7}{c}{ Per cent fatty acid } \\
\cline { 3 - 9 } & & $12: 0$ & $14: 0$ & $16: 0$ & $16: 1$ & $18: 0$ & $18: 1$ & $18: 2$ & Others* \\
\hline \multirow{2}{*}{ American } & Diet $\ddagger$ & 2.8 & 3.2 & 26.2 & 2.8 & 8.9 & 42.4 & 12.6 & 1.1 \\
& Adipose tissue & 0.4 & 3.0 & 22.9 & 6.3 & 5.8 & 48.2 & 10.2 & 1.3 \\
\multirow{2}{*}{ Japanese } & Diet (13) & 1.8 & 2.9 & 18.6 & 2.5 & 5.2 & 32.7 & 26.0 & 10.3 \\
& Adipose tissue & 0.2 & 2.6 & 21.5 & 8.0 & 3.6 & 43.0 & 16.5 & 2.6 \\
\hline
\end{tabular}

* Including linolenic and all acids with 20 or more carbon atoms per molecule up to 22:6.

$\ddagger$ Brown, Helen B. 1968. Personal communication. 
the national diets does indicate possible relationships (Table X). Compared to their diets, adipose of both groups contains lower proportions of lauric, myristic, stearic, and linoleic acids, and higher of palmitoleic and oleic acids. The higher proportions of palmitoleic and oleic acids in adipose imply that this tissue may be enriched by synthesis or selective sequestration of these acids. A group difference is seen only with palmitic acid, the Japanese adipose having more than the diet while the American adipose has less. This group difference may be attributed to the relative proportions of fat and carbohydrate in the diets and their effects on endogenous fatty acid synthesis, possibly favored in Japanese by high carbohydrate and suppressed in Americans by high fat. The closeness of the proportions of adipose palmitic acid in the two groups, in spite of greater diet differences, may be the result of a homeostatic mechanism controlling the proportion of palmitic acid. A1though for linoleic acid the daily intake per person is estimated for Americans at 10.5-12.5 $\mathrm{g}$ and for Japanese at $8.9 \mathrm{~g}(13,27,40)$ the intake per unit of body weight of both groups is probably the same since Japanese weigh about $20 \%$ less than Americans of comparable height. The striking difference in adipose linoleic between the groups may be due to greater dilution by other acids in Americans. In Japanese linolenic acid and acids with 20 or more carbon atoms per molecule, whereas expected to be in a high proportion in adipose tissue due to the frequent ingestion of fish, occurred with a surprisingly low proportion. The reason may be that these acids are consumed at a low level; they comprise about $10 \%$ of the total fat intake of about $36 \mathrm{~g} /$ day per caput. Although the low level in adipose tissue could not be measured accurately, Japanese appeared to have significantly more of these acids than did Americans.

A relationship between arteriosclerosis and fatty acids seems likely but is poorly defined at present. Studies have shown that alteration of diet fats may modify the morbidity and mortality from coronary heart disease while they lower serum cholesterol and alter the fatty acid composition of adipose tissue (41-44). The uncertain relationship of specific fatty acids to arteriosclerosis is due to observations that different acids correlate with different measures of arteriosclerosis. In the high coronary risk American population the higher proportion of oleic acid in adipose fat and its increase with age are prominent (16). In arteries the proportion of oleic acid in cholesterol esters is higher in arteriosclerotic lesions than in normal intima (45). While palmitic acid of adipose tissue correlates with plasma cholesterol concentration (11), several other adipose acids have been observed to correlate significantly with the morphological extent of coronary arteriosclerosis (12). Similar studies have not been performed in Japa- nese. Thus although a number of potentially important significant differences distinguish the adipose composition and possibly the fatty acid metabolism of Japanese and Americans we cannot at present identify those that may be crucial for the disparity in the development of the disease.

Investigation of this problem may be greatly aided by two experiments of nature currently in progress. Between 1962 and 1966 the adipose composition of Cleveland men appears to have changed significantly, e.g., in Caucasian men the proportions of oleic acid becoming lower, 50.6 vs. $48.5 \%$, and of linoleic acid becoming higher, 8.6 vs. $10.2 \%$ (46), indicating an increased ingestion of vegetable fats. In Japan during the last decade, the diet has been steadily increasing in the content of fat and in the proportion of fat derived from animal sources (13). No data on possible Japanese adipose changes are available. If these trends continue in each nation and ultimately affect the morbidity and mortality from arteriosclerosis, future comparisons of Japanese and Americans may be able to identify more definitely the fatty acids crucial to the pathogenesis of the disease.

\section{ACKNOWLEDGMENTS}

We wish to acknowledge the generous aid of the Department of Pathology, Case Western Reserve University, for providing tissue specimens and necropsy data, Dr. Yuichiro Goto and faculty members of School of Medicine, Keio University, for counsel, Professor Kiyoshi Sekita and members of the Department of Biochemistry, Keio University, for advice and use of laboratory facilities, Mr. Tsuda and staff of the Kitasato Memorial Medical Library, Keio University, for literature searches, and Miss Donna M. Burych for computer programming.

This study was supported by grants from the U. S. Public Health Service (HE 5284, HE 6304, HD 00669, and GM 12302), American Heart Association, Deutsche Forschungs gemeinschaft, and the Frackleton Memorial Fund of University Hospitals of Cleveland.

\section{REFERENCES}

1. Insull, W., Jr., P. D. Lang, B. Hsi, and S. Yoshimura. 1968. Fatty acid composition of adipose tissue in Japanese and Americans. Circulation. 38:(Suppl. 6): 10.

2. 1966 World Health Statistics Annual Vol. I. Vital Statistics and causes of death. World Health Organization, Rome.

3. Johnson, K. G., K. Yano, and H. Kato. 1968. Coronary heart disease in Hiroshima, Japan: report of a 6 year period of surveillance. 1958-1964. Amer. J. Public Health Nat. Health. 58: 1355.

4. Gordon, T. 1967. Further mortality and experience amonir Japanese Americans. Public Health Rep. 82: 973.

5. Gore, I., A. E. Hirst, Jr., and Y. Koseki. 1959. Coml arison of aortic atherosclerosis in the United States, Japan and Guatemala. Amer. J. Clin. Nutr. 7: 50.

6. Gore, I., W. B. Robertson, A. E. Hirst, G. G. Hadley, and Y. Koseki. 1960. Geographic differences in the 
severity of aortic and coronary atherosclerosis. Amer. J. Pathol. 36: 559.

7. Keys, A., N. Kimura, A. Kusukawa, B. Bronte-Stewart, N. Larsen, and M. H. Keys. 1958. Lessons from serum cholesterol studies in Japan, Hawaii and Los Angeles. Ann. Intern. Med. 48: 83.

8. Moore, F. E., and T. Gordon. 1967. Serum cholesterol levels in adults. United States. 1960-1962. Public Health Service Publication No. 1000, Series 11, No. 22. Washington, D. C.

9. Kinsell, L. W., J. Partridge, L. Boling, S. Margen, and G. Michaels. 1952. Dietary modification of serum cholesterol and phospholipid levels. J. Clin. Endocrinol. Metab. 12: 909 .

10. Ahrens, E. H., Jr., J. Hirsch, W. Insull, Jr., T. T. Tsaltas, R. Blomstrand, and M. L. Peterson. 1957. The influence of dietary fats on serum lipid levels in man. Lancet. 1: 943.

11. Insull, W., Jr., H. B. Houser, and A. S. Littell. 1968. Palmitic acid and other acids of adipose tissue lipids and the concentrations of serum total cholesterol in man. Circulation. 38 (Suppl. 6) : 9.

12. Insull, W., Jr., P. D. Lang, and B. Hsi. 1968. Adipose tissue fatty acids and extent of coronary atherosclerosis. Circulation. 38 (Suppl. 6) : 11.

13. Insull, W., Jr., T. Oiso, and K. Tsuchiya. 1968. The diet and nutritional status of Japanese. Amer. J. Clin. Nutr. 21: 753.

14. Annon. 1959. Net weight standards for men and women. Statis. Bulletin of the Metropolitan Life Insurance Company. 40: 2 .

15. Siegel, D. 1962. ABCC-JNIH adult health study, Hiroshima and Nagasaki, 1958-60 height, weight tables. Atomic Bomb Casualty Commission Technical Report. 19-62.

16. Insull, W., Jr., and G. E. Bartsch. 1967. Fatty acid composition of human adipose tissue related to age, sex, and race. Amer. J. Clin. Nutr. 20: 13.

17. Cook, R. P. 1958. Cholesterol: Chemistry, Biochemistry and Pathology. Academic Press Inc., New York. 484-491.

18. Vague, J., and J. C. Garrigues. 1956. Recherches sur la composition du tissu adipeux humain et nottament sa teneur en steroides. Ann. Endocrinol. 16: 805.

19. Horning, E. C., E. H. Ahrens, Jr., S. R. Lipsky, F. H. Mattson, J. F. Mead, D. A. Turner, and W. H. Goldwater. 1964. Quantitative analysis of fatty acids by gasliquid chromatography. J. Lipid Res. 5: 20.

20. Siegel, S. 1956. Nonparametric Statistics for the Behavioral Sciences. McGraw-Hill Book Company, New York. 127.

21. Heiduschka, A., and C. Handritschk. 1928. Uber Menschenfett. Biochem. Z. 197: 404.

22. Hirsch, J., J. W. Farquhar, E. H. Ahrens, Jr., M. L. Peterson, and W. Stoffel. 1960. Studies of adipose tissue in man: A microtechnique for sampling and analysis. Amer. J. Clin. Nutr. 8: 499.

23. Gellhorn, A., and P. A. Marks. 1961. The composition and biosynthesis of lipids in human adipose tissue. J. Clin. Invest. 40: 925.

24. Dabney, W. T., III. 1961. Fatty acid composition of adipose tissue in patients with carcinoma of the breast. J. Nat. Cancer Inst. $27: 25$.

25. Scott, R. F., A. F. Daoud, A. Gittelsohn, E. Opalka, R. Florentin, and F. Goodale. 1962. Lack of correlation between fatty acid patterns in adipose tissue and amount of coronary arteriosclerosis. Amer. J. Clin. Nutr. 10: 250 .
26. Hegsted, D. M., C. W. Jack, and F. J. Stare. 1962. The composition of human adipose tissue from several parts of the world. Amer. J. Clin. Nutr. 10: 11.

27. Dayton, S., M. L. Pearce, S. Hashimoto, L. L. Fakler, E. Hiscock, and W. J. Dixon. 1962. A controlled clinical trial of a diet high in unsaturated fat. N. Engl. $J$. Med. 266: 1017.

28. Lee, K. T., A. G. Shaper, R. F. Scott, F. Goodale, and W. A. Thomas. 1962. Geographic studies pertaining to arteriosclerosis: comparison of fatty acid patterns of adipose tissue and plasma lipids in East Africans with those of North American white and Negro groups. Arch. Pathol. 74: 481.

29. Sweeney, M. J., J. N. Etteldorf, L. J. Throop, D. L. Timma, and E. L. Wrenn. 1963. Diet and fatty acid distribution in subcutaneous fat and in the cholesteroltriglyceride fraction of serum of young infants. J. Clin. Invest. $42: 1$.

30. Remenchik, A. P., and J. Bernsohn. 1963. Relationships between the composition of adipose tissue and the total fat content of the body. Ann. N. Y. Acad. Sci. 110: 754.

31. Scott, R. F., K. T. Lee, D. N. Kim, E. S. Morrison, and F. Goodale. 1964. Fatty acids of serum and adipose tissue in six groups eating natural diets containing 7 to 40 per cent fat. Amer. J. Clin. Nutr. 14: 280.

32. Christakis, G. J., S. H. Rinzler, M. Archer, S. A. Hashim, and T. B. van Itallie. 1965. Effect of a serum cholesterol lowering diet on composition of depot fat in man. Amer. J. Clin. Nutr. 16: 243.

33. Goto, Y., and H. Nakamura. 1963. Fatty acid constitution of the depot fat. Saishin Igaku. 18: 2419.

34. Imaichi, K., J. Fukuda, K. Oyama, and A. Mukawa. 1965. Effect of sample site on fatty acid composition of adipose tissue. J. Biochem. 58: 463.

35. Kumagai, M.; and E. Fujimoto. 1966. Studies on the fatty acid composition of body fat with particular reference to body weight and age. Acta Pediat. Jap. 70: 155

36. Insull, W., Jr., H. B. Houser, and A. S. Littell. 1966. Fatty acid composition of human adipose tissue: relationship to body weight, age and serum cholesterol. J. Clin. Invest. 45 : 1026. (Abstr.)

37. Hilditch, T. P., and P. N. Williams. 1964. The chemical constitution of natural fats. John Wiley \& Sons Inc., New York. 4th edition. 122

38. Dayton, S., S. Hashimoto, and M. L. Pearce. 1967. Adipose tissue linoleic acid as a criterion of adherence to a modified diet. J. Lipid Res. 8: 508.

39. Christakis, G., E. L. Severinghaus, Z. Maldonado, F. C. Kafatos, and S. A. Hashim. 1965. Crete: a study in the metabolic epidemiology of coronary heart disease. Amer. J. Cardiol. 15: 320 .

40. National Diet-Heart Study Group. 1968. National dietheart study final report. Circulation. 37 (Suppl. 1) : 126.

41. Leren, P. 1966. The effect of plasma cholesterol lowering diet in male survivors of myocardial infarction. Acta Med. Scand. Suppl. 466.

42. Christakis, G., S. H. Rinzler, M. Archer, G. Winslow, S. Jampel, J. Stephenson, G. Friedman, H. Fein, A. Kraus, and G. James. 1966. The anti-coronary club: a dietary approach to the prevention of coronary disease. A seven year report. Amer. J. Public Health Nat. Health. 56: 299.

43. Turpeinen, O., M. Miettinen, M. J. Karvonen, P. Roine, M. Pekkarinen, E. J. Lehtosuo, and P. Alivirta. 1968. Dietary prevention of coronary heart disease: long-term 
experiment. I. Observations on male subjects. Amer. J. Clin. Nutr. 21: 255.

44. Dayton, S., M. L. Pearce, H. Goldman, A. Harnish, D. Plotkin, M. Schickman, M. Winfield, A. Zager, and W. J. Dixon. 1968. Controlled trial of a diet high in unsaturated fat for prevention of atherosclerotic complications. Lancet. 2: 1060.
45. Geer, J. C., and M. Guidry. 1964. Cholesterylester composition and morphology of human normal intima and fatty streaks. Exp. Mol. Pathol. 3: 485.

46. Insull, W., Jr., P. D. Lang, and B. Hsi. 1968. Comparison between 1962 and 1966 of adiposes tissue fatty acids in Caucasian and Negro Americans. Circulation. 38 (Suppl. 6) : 10 . 